\title{
Nachrichten über die physikalische Gesellschaft.
}

Im Laufe des Jahres 1881 wurden folgende neue Mitglieder in die Gesellschaft aufgenommen:

Heir Dr. Theel, Dr. Lensch, Dr. Möller jun., Dr. Voss, Dr. Scuönıcu (Innsbruck), Dr. Rotu (Leipzig), Dr. Hammerc (Innsbruck), P'rof. Bruhns, Dr. Kalischer, Herr König, Prof. Börnstein, Dr. Wrinstein.

A usgeschieden: Dr. E. Conn, Dr. Lenscu, Dr. F. Moller.

Gestorben: Prof. Dr. Bruhns (Leipzig), Prof. Dr. Borchardt, Prof. Hein'r\%.

Also waren Mitglieder:

IIr. I)r. II. Aron.

- Irof. Dr. Aroniold.

- Artorl: in Elberfeld.

-.. Prof. Dr. August.

- Prof. Dr. Auwers.

- Prof. Dr. Barentin.

- Dr. Becker in Darmstadt.

- Prof. Dr.v. Bevт $z$ in München.

- Dr. Benolt.

- Dr. Bretholo in Rohnsdorf.

- Prof. Dr. W. v. Bezold in München.

- Dr. Biermaxs.

- Prof. Dr. Börnstein.

- Dr. Bötrger.

- Prof. Dr. E. du Bois-ReyMOND.

- Prof. Dr. P. du BoIs-ReYMOND in Tübingen.

Hr. Prof. Dr. Brû́cke in Wien.

- Telegraphendirector Brunner in Wien.

Prof. Dr. Bruns (jetzt in Leipzig).

- Dr. Burckhardt in Basel.

- Prof. Dr. Buys - Ballot in Utrecht.

- Dr. Caspary.

- Prof. Dr. A. Christiani.

- Prof. Dr. Christoffel in Strassburg.

- Prof. Dr. Clausius in Bonn.

- Dr. Cochius.

- Dr. Dengs in Constanz.

- Fabrikant Dr. Deıte.

-. Dr. Dulk.

- Prof. Dr. W. Dumas.

- Prof. Dr. EichHorn.

- Prof. Dr. v. Boguslawski. - Prof. Dr. E. O. Erdmann.

- Prof. Dr. Boltzmann in Wien. - Ernicke.

- Prof. Ir. F. Bratin in Strass- - Dr. Ewald. burg.

- Dr. O. Brats.

- Prof. I)r. Brir. in München.

- Dr. Brix in Charlottenburg.

Fortschr. d. Phys. XXXIII.

- Prof. Dr. v. Feilitzsch in Greifswald.

- Prof. Dr. Fıck in Würzburg.

- Prof. Dr. Finkener. 
Hr. Telegrapheningenieur FrISCHEN.

- Dr. E. Fischer.

- Prof. Dr. A. Flohr.

- Prof. Dr. R. Franz.

- Dr. Freund.

- Dr. J. Friedländer.

- Dr. Frölich.

- Prof. Dr. Fromme in Marburg.

- Prof. Dr. Fuchs in Heidelberg.

- Mechanikus Furss.

- Dr. GAD in Würzburg.

- Gerlach.

- Director Gallenkamp.

- Dr. Giése.

- Dr. P. Glan.

- Dr. Goldstein.

- Dr. Th. Gross.

- Prof. Dr. Grossmann.

- Prof. Dr. Groth in Strassburg.

- Prof. Dr. Grotrian in $\Lambda$ achen.

- Dr. Grunmach.

- Mechanikus Hãnsch.

- Dr. E. Hagen-Bessel.

- Prof. Dr. Hagenbach in Basel.

- Telegraphenfabrikant J. G. HaISKE.

- Dr. M. Hamburger.

- Dr. Hammerl (Innsbruck).

- G. Hansemann.

- Prof. Dr. Guido Hauck.

- Prof. Dr. Helmholtz.

- Dr. A. Hempel.

- Dr. Henoch.

- Dr. Heyden.

- Prof. Dr. Hirschberg.

- Dr. Hirschwald.

-. Prof. Нон in Bamberg.

- Dr. Hohnhorst.

- Dr. L. Holz.

- Prof. Dr. R. Hoppe.

- Dr. Hutr in Brandenburg.

- Prof. Dr. H. JACobson.

- Dr. Jagor.

- Dr. Jungk.

- Dr. Kalischer.

- Prof. Dr. G. Karsten in Kiel

- Prof. Dr. Ketteler in Bonn.

-- Prof. Kiessling in Hamburg.

- Prof. Dr. G. Kirchioff.

- Prof. Dr. KLeıN in München.
Hr. Prof. Dr. Knoblauch in Halle.

- König.

- Prof. Dr. Kohlrauscil in Würzburg.

- Prof. Dr. Kossack.

- Prof. Dr. Krech.

- Dr. Kremers in Mainz.

- Prof. Dr. Kronecker.

-- Prof. Dr. Hugo Kronecker II.

- Prof. Dr. Fr. Kruse.

- Prof. Dr. Kundrin Strassburg.

- Prof. Dr. Lampe.

- Prof. Dr. Lannolt.

- Dr. Lange.

- Prof. Dr. Lieberkūins in Mar. burg.

- Prof. Dr. Lienseci in Breslau.

- Ir. LAEW.

-- Prof. Dr. Ludwe in Leipzig.

- Dr. Lû̃веск.

- Dr. Maschкe.

-.. Prof. O. E. Mever in Breslau.

- Dr. ast. Möller in Schweden.

- Dr. James Moser in Berlin.

- Prof. Dr. H. Munk.

- Dr. Mû́iler-Erzbach in Bremen.

- Papierfabrikant Dr. Mǘr.er.

- Dr. Müller jun.

- Prof. Dr. A. Müttricı in Eberswalde.

- Dr. Natani.

- Prof. Dr. F. Neesen.

- Prof. Neubert in Dresden.

- Prof. Dr. C. Neumane in Leipzig.

- Dr. PEtri.

- Prof. Dr. Oberneck in Halle a./S.

- Prof. Dr. v. Orettingen in Dorpat.

- Dr. Ourtmann.

- Prof. Dr. PaAlzow.

- B. Pensky.

- Prof. Dr. Praundler in Innsbruck.

- Prof.Dr. Pochenamer in Kiel.

- Dr. Poske.

- Prof. Dr. Pringsheim.

- Prof. Dr. G. Quincke in Heidelberg.

- Dr. Raduu in Paris. 
Hr. Prof. Dr. Radicke in Bonn. IIr. Wil. Siemens.

- Oberl. Reichel in Charlotten- - Prof. Silow (Siloff) in Mosburg.

- Dr. Reincke, Sanitätsrath. kau.

- Dr. W. Reiss.

- Dr. Sklarek.

-- Prof. Dr. Riecke in Göttingen.

- Prof. Rokber.

- Prof. Dr. Spörer in Potsdam.

- Prof. Dr. Rosenthal in Er-

- Dr. Steiner in Erlangen.

- Dr. Theel.

- Dr. G. Thiessen. langen.

- Prof. Dr. Tyndall in London.

- Dr. Rosochatius.

- Dr. Roth (Leipzig).

-. Prof. Dr. Roth.

- Prof. Dr. RödorfF.

- Dr. Vetrin.

- Prof. Dr. Virchow.

- Prof. Dr. Vogel.

- Dr. Voss.

- Prof. Rôlumann in Chemnitz.

- Dr. Saalschôttz in Königsberg i. Pr.

- Oberlehrer Schellhammer in Dresden.

- Dr. Schelske.

- Dr. Schemmel in Berlin.

- Schlegel.

- Ir. Schönach (Innsbruck).

- Prof. Dr. Warburg in Freiburg i. Br.

- Prof. Dr. Wangerin.

- Prof. Dr. Werer in Zürich.

- Prof. Dr. Weiers'rrass.

- Prof. Dr. Weingarten.

- Dr. Weinstein.

-- Dr. Weissenborn.

- Dr. Wernicke.

- Prof. Dr. G. Wiedemann in Leipzig.

- Dr. P. Scholz.

..- Kanzleirath Schotte.

- Dr. Schröder.

-. Ir. Ad. Seebeck.

- Dr. E. Schulze.

- Dr. Schulze-Berge.

-- Dr. Schumann.

- Prof. Dr. B. Schwalbe.

- Dr. Wr. Siemens.

- Prof. Dr. E. Wiedemann in Leipzig.

- Prof. Dr. Worpitzky.

- Wốlfinghof.

- Prof. Dr. Wollner in Aachen.

- Dr. v. ZaHN in Leipzig.

- Prof. Dr. Zöllner in Leipzig ${ }^{*}$ ).

*) kïrzlich gestorben.

Geschlossen am 31. December 1881. 